\title{
Lime potentials as biopreservative as alternative to chemical preservatives in pineapple, orange and watermelon juice blend
}

\author{
${ }^{1, *}$ Olaniran, A.F., ${ }^{2}$ Afolabi, R.O, ${ }^{2}$ Abu, H.E,${ }^{2}$ Owolabi, A., ${ }^{1}$ Iranloye, Y.M., ${ }^{2}$ Okolie, C.E. \\ and ${ }^{2}$ Akpor, O.B. \\ ${ }^{1}$ Department of Food Science and Nutrition, Landmark University, PMB 1001, Omu-Aran, Kwara State \\ ${ }^{2}$ Department of Microbiology, Landmark University, PMB 1001, Omu-Aran, Kwara State, Nigeria
}

\section{Article history:}

Received: 6 February 2020

Received in revised form: 13

March 2020

Accepted: 14 March 2020

Available Online: 14 July

2020

\section{Keywords:}

Lime,

Pineapple,

Orange-water-lemon juice

blends,

Biopreservation,

Chemical preservatives

\section{DOI:}

https://doi.org/10.26656/fr.2017.4(6).057

\begin{abstract}
The major challenge influencing fruits economic value is the relatively short shelf-life. This study preserved fruit juice blend from pineapple, watermelon and orange using lime juice as biopreservative comparing its effectiveness with ascorbic acid and citric acid as chemical preservatives during storage at ambient temperature $\left(27 \pm 2^{\circ} \mathrm{C}\right)$ for five weeks. The acceptability of the juice by consumer, biochemical changes and microbial load was also evaluated on a weekly basis. From the results, all the samples were acceptable on a 9-point hedonic scale (8.70-8.90) with 1\% lime biopreserved juice blend was the most preferred. This shows that that lime effectively controlled the rate at which increase $\mathrm{pH}$ and decrease of TTA occurred during storage by double-fold when compared with ascorbic and citric acid used in the study. A minimal decrease in $\mathrm{pH}$ of $0.75 \%$ was documented during the five weeks of study. The specific gravity of the juice was relatively table during storage except for the unpreserved juice. Lime addition at 2 and $4 \%$ effectively suppressed fungal growth in the juice for five weeks of storage. Lime juice added as biopreservative at $4 \%$ showed the best bacteriostatic and fungistatic performance while the consistent increase in the bacteria growth from $60 \times 10^{2}-11 \times 10^{10}$ $\mathrm{CFU} / \mathrm{mL}$ was recorded in unpreserved at ambient temperatures during storage. Ascorbic acid and citric acid as preservative effectively inhibited microbial growth of bacterial and fungal for 2 weeks, followed by a steady increase from $16 \times 10^{1}-17 \times 10^{3}, 20 \times 10^{2}$ $62 \times 10^{2}$ and $20 \times 10^{2}-36 \times 10^{4} ; 21 \times 10^{2}-48 \times 10^{2} \mathrm{CFU} / \mathrm{mL}$ respectively. Low Bacterial count was recorded in juice preserved with $1 \%$ lime $\left(70 \times 10^{1} \mathrm{CFU} / \mathrm{mL}\right), 2 \%$ lime preserved $\left(41 \times 10^{2} \mathrm{CFU} / \mathrm{mL}\right)$ and $4 \%$ lime $\left(13 \times 10^{1} \mathrm{CFU} / \mathrm{mL}\right)$ at week 4 and week 5 respectively. The study established that lime is a good biopreservative with antimicrobial effect can serve as a replacement for chemical preservatives.
\end{abstract}

\section{Introduction}

Fruits are a seasonal crop in nature have driven researches on the processing of fruit juices and their preservation for usage through off-season (Almeida et al., 2019). 20-25\% estimated postharvest losses due to post- due to prompt inadequate storage and transportation facilities (Igbinadolor et al., 2017). Increasing awareness in citrus fruits consumption across the world as vital and good sources of folate, vitamin C, minerals and dietary fibre (Khan et al., 2017). Fruits like banana, oranges, pineapple, watermelon, pawpaw, cashew abound in Nigeria and are consumed heavily in the season because storage technology is not available to preserve the excess production (Akusu et al., 2016). Economic growth and changes in dietary patterns have made both the production and consumption of fruit and vegetables increasingly important. Orange juice (Citrus sinensis) is the most consumed fruit juice in the world usually extracted from endocarp of the fruit. It significantly contributes to daily intakes of micronutrients as it a good source of folate, vitamin C and flavanone (Chanson-Rolle et al., 2016). Pineapple fruit edible part accounts for its $60 \%$ of the fresh fruit with $85 \%$ moisture content (Hounhouigan et al., 2014). Watermelon (Citrullus lanatus) is a valuable source of readily bioavailable natural antioxidants such as carotenoids especially $\beta$-carotene, citrulline, lycopene, vitamin $\mathrm{A}$ and $\mathrm{C}$. Its flesh is about $91 \%$ water per weight. These functional constituents play important roles in protection against cardiovascular disorders and 
cancer insurgence (Shanely et al., 2016). The high moisture content of fruit juice predisposes them to microbial spoilage by bacteria, molds, and yeasts, since most are acid tolerant (Aderinola and Adeniran, 2015). Chemical are used as food preservatives such as sodium benzoate, benzoic acid, ascorbic acid, and citric acid serving as antimicrobial agents inhibiting the growth of bacteria, molds and other microorganisms (Usaga et al., 2017). There is decrease in demands of food products preserved with artificial preservatives consequent to the adverse effect of long-term consumption on the health of consumers (Olaniran and Abiose, 2018). Lime (Citrus aurantifolia) a citrus fruit is a household essential ingredient in numerous food or in cuisine worldwide sequel to its distinctive sour taste. Its juice can directly squeeze to food during cooking (Cruz-Valenzuela et al., 2016). Lime juice contains organic acid which is majorly citric acid that can serve as a natural preservative. Good antimicrobial agents and can be gotten from major citrus family such as lime, lemon, orange and another genus in the group (Ezeigbo et al., 2015). The blending of different fruits juices increases the nutritional profile and the viability of the product (Okwori et al., 2017). Hence, the study examined the biopreservation of watermelon, pineapple orange and lime mix using the lime as the preservative. With the aim of assessing the acceptability of the new juice blends, study the effectiveness of lime as bio preservative in the juice blend compared to ascorbic acid and citric acid using enumeration of microbial load and changes in some physicochemical qualities of the juice during storage for 5 weeks at room temperature while reducing postharvest losses.

\section{Materials and methods}

2.1 Preparation of the pineapple, watermelon-orange juice blend

For preparation of the juice blend, pineapple, watermelon and orange were used. A total of $3 \mathrm{~kg}$ of each of the fresh, ripe fruits were respectively washed under running water, drained in colanders, peeled and diced into cubes. Each juice of the edible parts of the respective fruits was extracted separately using juice extractor (Imarflex IM-3180, Quezon City, Philippines). Following extraction, the pineapple, orange, and watermelon (PWO) juice were mixed in the ratio of 10:50:40 (v/v) respectively to obtain the blends which were homogenized for 10s (Kaddumukasa et al., 2017).

\subsection{Preparation of preservative filtrates}

Fresh lime fruit was handpicked from an orchard in Obafemi Awolowo University and transported to Food processing laboratory. The fruits were washed, squeezed and the pulp was screened using by the mesh (Ameh et $a l ., 2015)$. The fresh juices were dispensed in bottles and used for further processing. A glass jar of PWO juice, containing no preservative was maintained as a positive control. Five other separate jars were engaged with five different pre-treatments. 4\% ascorbic (PWOA) acid and $4 \%$ citric acid (PWOC) were used as preservatives in this study. Chemical preservatives of $1 \%$ namely ascorbic and citric acid were added to the fruit blend while lime was added at a different percentage of lime concentration $1 \%$ (PWOL1), 2\% (PWOL2) and 4\% (PWOL4) to the fruit blends.

\subsection{Sensory analysis}

To estimate consumers' acceptability, the following sensory attributes were investigated: aroma, color, flavor, sweetness, mouthfeel and overall impression. A ninepoint structured hedonic scale test $(9=$ extremely like - 1 $=$ extremely dislike) was used for the assessment of overall acceptance of the freshly prepared juice blend, with and without the respective preservatives.

For the investigation, the samples were served in a sequential manner in cups containing $25 \mathrm{~mL}$ of the respective juice treatments and codified with three random digits. The sensory evaluation was conducted with 60 panelists (30 females and 30 males) comprising of students and faculty of Landmark University, OmuAran, Nigeria aged between 18 and 50 years. The inclusion criteria in being selected as a panelist on condition of regular consumption of the juice blend (Olaniran et al., 2019).

\subsection{Determination of physical characteristics}

$\mathrm{pH}$ was determined using a $\mathrm{pH}$ meter (Jenway model 6505). Before use, the $\mathrm{pH}$ meter was calibrated using standard buffers of 7.0, 4.0 and 9.2. After calibration, $\mathrm{pH}$ readings were read and documented only when equilibrium $\mathrm{pH}$ was reached. Titratable acidity and specific gravity were determined as described in AOAC (2010).

\subsection{Microbial enumeration}

During the storage period, the microbial analysis was carried out on a weekly basis for 5 weeks, using nutrient agar (for total bacterial count), De Man, Rogosa and Sharpe agar for enumeration of lactic acid bacteria and potato dextrose agar, for estimation of the fungal count, using the standard pour-plating method (APHA, 2011). Following juicing, 10-fold serial dilutions (containing $1.0 \mathrm{~mL}$ of juice in $9.0 \mathrm{~mL}$ of water) of freshly prepared samples $(1.0 \mathrm{~mL})$ of samples were used for enumeration of microbial populations over a range of ten. The enumeration was repeated on a weekly basis. Nutrient agar was used for microbial enumeration for the total viable count, Man de Rogosa and Sharpe (MRS) for 
lactic acid bacteria count, Eosin methylene blue agar for the coliform count while MacConkey agar was used for enumeration of enteric bacteria. Culture plates incubated at $37^{\circ} \mathrm{C}$ and examined after overnight $(20-24 \mathrm{hrs})$ incubation. Sabouraud Dextrose agar plates were used for enumeration of yeasts and molds incubated for 3 days at $28^{\circ} \mathrm{C}$ and examined.

\subsection{Determination of specific gravity}

The specific gravity of each sample of pineapple, watermelon and orange juice was determined by using a hydrometer (HB-Durac 61801, Novatech USA) by dipping the spindle into the different juices; water was used for rinsing the hydrometer after each reading. The readings were taken directly from the upper meniscus (Ibrahim et al., 2013).

\subsection{Determination of total soluble solids}

Two drops of fresh and preserved pineapple, watermelon and orange juice on refractometer lens (Hanna HI 96801, Hanna Instruments Inc., Woonsocket, RI, USA) using refractometric method as described by Olaniran et al. (2019). Refractive index was read directly from the prism scale and recorded in ${ }^{\circ}$ Brix.

\subsection{Statistical analysis}

Duncan Multiple Range Test (DMRT) was set at 5\% level of significance to test for any significant difference and compare the level of effectiveness of chemical preservatives and biopreservative on pineapple, watermelon and orange juice during storage across different treatments on all the parameter evaluated during five weeks of the study. The means of the results obtained from all analysis conducted were calculated and separated by using MS Excel 2016.

\section{Results and discussion}

\subsection{Consumer acceptability of the lime preserved juice}

The panel scores for the colour ranged from 8.698.85 . There was no significant difference in the colour of pineapple watermelon orange juice preserved with ascorbic acid (PWOA), citric acid (PWOC), 2\% lime (PWOL2) and 4\% lime (POWL4) as they compete favorably. Also, the scoring for the taste of the juice for unpreserved pineapple watermelon orange juice (PWO) and those preserved with $1 \%$ lime (POWL1) was comparable and had no significant difference. A similar observation was recorded between PWOL2 and POWL4 in taste withs scores of 8.44 and 8.40 respectively. All samples were acceptable and compared favorably with the control, with the juice preserved with $1 \%$ lime showing the best overall acceptability. The flavour of the juice was improved in PWOL1 (8.75) having the highest score than the control (8.65) and there was a significant difference. The flavour of PWOL2 (8.57) and PWO (8.60) was comparable with no significant difference. However, increasing the lime concentration to $4 \%$ in PWOL4 significantly affected the flavour. This may be due to the stringent/ strong sour taste and in flavour of the lime which became noticeable as the level of lime increased in the juice (Jittanit et al., 2013). From Table 1 , there was no remarkable difference in the appearance of the juice as the scores ranged from 8.84 and 8.85 for all the juice sample. This observation showed that addition of lime up to $4 \%$ of the juice did not affect the physical perception of the consumer/panelist of the juice which is a good attribute for not altering one the most qualitative parameters for acceptance of any products. All the juice samples were highly acceptable as no sample was scored below 8 points $(8.75-8.90)$. From the results, the addition of lime as preservative did not negatively affect the acceptance of the juice thus recommended.

\subsection{Potentials of lime as preservative on microbial load}

All the freshly produced juice samples either preserved or unpreserved as shown in Table 2, showed no growth of microorganisms. However, after one week of storage at ambient temperature no counts were recorded for all preserved juice on the bacteria, LAB and fungi plates except on those without preservative $\left(60 \times 10^{2}, 17 \times 10^{1}\right.$ and $17 \times 10^{3} \mathrm{CFU} / \mathrm{mL}$ respectively) which was the control sample. PWO also showed the formation of gas in the bottle. The consistent increase in

Table 1. Consumers acceptability of pineapple, watermelon orange juice blends

\begin{tabular}{ccccccc}
\hline Attribute & PWO & PWOA & PWOC & POWL1 & PWOL2 & PWOL4 \\
\hline Colour & $8.85 \pm 0.25^{\mathrm{a}}$ & $8.69 \pm 0.03^{\mathrm{b}}$ & $8.71 \pm 0.03^{\mathrm{b}}$ & $8.83 \pm 0.02^{\mathrm{a}}$ & $8.84 \pm 0.01^{\mathrm{a}}$ & $8.71 \pm 0.03^{\mathrm{b}}$ \\
Taste & $8.55 \pm 0.02^{\mathrm{a}}$ & $8.42 \pm 0.03^{\mathrm{b}}$ & $8.45 \pm 0.03^{\mathrm{b}}$ & $8.51^{\mathrm{a}} \pm 0.05$ & $8.44 \pm 0.00^{\mathrm{b}}$ & $8.40 \pm 0.03^{\mathrm{b}}$ \\
Flavour & $8.60 \pm 0.02^{\mathrm{b}}$ & $8.25 \pm 0.05^{\mathrm{d}}$ & $8.30 \pm 0.06^{\mathrm{d}}$ & $8.75 \pm 0.08^{\mathrm{a}}$ & $8.57 \pm 0.05^{\mathrm{c}}$ & $8.35 \pm 0.04^{\mathrm{d}}$ \\
Perception & $8.85 \pm 0.01^{\mathrm{a}}$ & $8.82 \pm 0.07^{\mathrm{a}}$ & $8.80 \pm 0.03^{\mathrm{a}}$ & $8.84 \pm 0.00^{\mathrm{a}}$ & $8.85 \pm 0.00^{\mathrm{a}}$ & $8.85 \pm 0.02^{\mathrm{a}}$ \\
Overall Acceptability & $8.90 \pm 0.03^{\mathrm{a}}$ & $8.70 \pm 0.04^{\mathrm{b}}$ & $8.71 \pm 0.02^{\mathrm{b}}$ & $8.85 \pm 0.07^{\mathrm{a}}$ & $8.70 \pm 0.05^{\mathrm{b}}$ & $8.75 \pm 0.01^{\mathrm{b}}$ \\
\hline
\end{tabular}

PWO (without preservative); PWOA (Ascorbic acid preserved); PWOC (Citric acid preserved); PWOL1 (1\% Lime preserved); PWOL2 (2\% Lime preserved); PWOL4 (4\% Lime preserved).

According to Duncan multiple range test different superscripts on means connotes significantly difference $(p<0.05)$ along the column. 
Table 2. Comparative effect of lime as preservatives with ascorbic acid and citric acid on the microbial counts

\begin{tabular}{|c|c|c|c|c|c|c|}
\hline \multirow{2}{*}{ Samples } & \multicolumn{6}{|c|}{ Storage Period (Weeks) } \\
\hline & 0 & 1 & 2 & 3 & 4 & 5 \\
\hline \multicolumn{7}{|c|}{ Total bacterial count (colony-forming units/mL) } \\
\hline PWO & NIL & $60 \times 10^{2}$ & $28 \times 10^{3}$ & $26 \times 10^{5}$ & $36 \times 10^{7}$ & $11 \times 10^{10}$ \\
\hline PWOA & NIL & NIL & NIL & $16 \times 10^{1}$ & $52 \times 10^{2}$ & $17 \times 10^{3}$ \\
\hline PWOC & NIL & NIL & NIL & $54 \times 10^{1}$ & $20 \times 10^{2}$ & $36 \times 10^{4}$ \\
\hline PWOL1 & NIL & NIL & NIL & NIL & $70 \times 10^{1}$ & $28 \times 10^{2}$ \\
\hline PWOL2 & NIL & NIL & NIL & NIL & NIL & $41 \times 10^{2}$ \\
\hline PWOL4 & NIL & NIL & NIL & NIL & NIL & $13 \times 10^{1}$ \\
\hline \multicolumn{7}{|c|}{ Lactic acid bacterial count (colony-forming units $/ \mathrm{mL}$ ) } \\
\hline PWO & NIL & $17 \times 10^{1}$ & $34 \times 10^{2}$ & $48 \times 10^{3}$ & $73 \times 10^{4}$ & $36 \times 10^{5}$ \\
\hline PWOA & NIL & NIL & NIL & NIL & $40 \times 10^{3}$ & $11 \times 10^{4}$ \\
\hline PWOC & NIL & NIL & NIL & NIL & $54 \times 10^{4}$ & $48 \times 10^{5}$ \\
\hline PWOL1 & NIL & NIL & NIL & NIL & $48 \times 10^{1}$ & $56 \times 10^{1}$ \\
\hline PWOL2 & NIL & NIL & NIL & NIL & NIL & $48 \times 10^{1}$ \\
\hline PWOL4 & NIL & NIL & NIL & NIL & NIL & $12 \times 10^{1}$ \\
\hline \multicolumn{7}{|c|}{ Total fungal count (spore-forming units/mL) } \\
\hline PWO & NIL & $17 \times 10^{3}$ & $34 \times 10^{3}$ & $48 \times 10^{3}$ & $73 \times 10^{4}$ & $36 \times 10^{5}$ \\
\hline PWOA & NIL & NIL & NIL & $20 \times 10^{2}$ & $40 \times 10^{2}$ & $62 \times 10^{2}$ \\
\hline PWOC & NIL & NIL & NIL & $21 \times 10^{2}$ & $36 \times 10^{2}$ & $48 \times 10^{2}$ \\
\hline PWOL1 & NIL & NIL & NIL & NIL & $29 \times 10^{1}$ & $56 \times 10^{1}$ \\
\hline PWOL2 & NIL & NIL & NIL & NIL & NIL & NIL \\
\hline PWOL4 & NIL & NIL & NIL & NIL & NIL & NIL \\
\hline
\end{tabular}

$\mathrm{n}=3$. PWO (without preservative); PWOA (Ascorbic acid preserved); PWOC (Citric acid preserved); PWOL1 (1\% Lime preserved); PWOL2 (2\% Lime preserved); PWOL4 (4\% Lime preserved)

the bacteria growth from $60 \times 10^{2}-11 \times 10^{10} \mathrm{CFU} / \mathrm{mL}$ was recorded in unpreserved at the fifth week of storage. Ascorbic acid and citric acid as preservative effectively inhibited microbial growth of bacterial and fungal for 2 weeks, this was followed by a steady increase from $16 \times 10^{1}-17 \times 10^{3}, 20 \times 10^{2}-62 \times 10^{2}$ and $20 \times 10^{2}-36 \times 10^{4}$; $21 \times 10^{2}-48 \times 10^{2} \mathrm{CFU} / \mathrm{mL}$ for PWOA and PWOC respectively. Low bacterial count was recorded in PWOL1 $\left(70 \times 10^{1} \mathrm{CFU} / \mathrm{mL}\right)$ in week 4 and week 5 in PWOL2 $\left(41 \times 10^{2} \mathrm{CFU} / \mathrm{mL}\right)$ as well as PWOL4 $\left(13 \times 10^{1}\right.$ $\mathrm{CFU} / \mathrm{mL}$ ). It was observed that the bacterial count noted at week 5 in PWOL1, PWOL2 and PWOL4 were lower than the counts recorded in unpreserved at week 1 showing its effectiveness as preservatives. Lactic acid bacteria growth was observed in unpreserved juice samples all through 5 weeks of storage, after 3 weeks of storage in PWOA, PWOC, PWOL1 while in PWOL2 and PWOL4 at 4 weeks respectively. The PWOA and PWOC showed fungal growth after 2 weeks and PWOL1 after 3 weeks of storage, respectively. There was no fungal growth observed in PWOL2 and PWOL4 for the 5 weeks of study. Lime addition 2 and $4 \%$ effectively suppressed fungal growth in the juice for 5 weeks of storage. Lime juice added at 4\% showed the best bacteriostatic and fungistatic performance at ambient temperatures during the 5 weeks of storage. This may be attributed to the is phytochemical properties and antimicrobial ability (Ekanem and Ekanem, 2018). Rahman, (2011) reported inhibition of anaerobic facultative bacteria using lime fruit and also had significant antimycobacterial activity especially against the isoniazid-resistant strain of Mycobacteria (CamachoCorona, 2018). The microbial loads recorded during the study using lime either 1, 2 or $4 \%$ was within the limit of mesophilic aerobic bacteria permissible by International Commission on Microbiological Specification of Foods for food products which ought not to exceed $10^{3} \mathrm{CFUmL}$ ${ }^{-1}$ maximum (Batra et al., 2016).

\subsection{Effect of preservatives on the physical and} biochemicals parameters of pineapple watermelon orange blend

Addition of preservative significantly increased the acidity of the freshly preserved juice sample (Table 3). During storage increase in the titratable acidity was observed in most except in PWOL4 which was stable $(0 \%)$ all through the 5 weeks. The highest increase of $53 \%$ was recorded in unpreserved juice samples with the lowest $10.34 \%$ in those preserved with $2 \%$ lime. Ascorbic acid and citric acid preserved samples recorded 40 and $37.03 \%$ which was higher than those preserved with lime that ranged between $0-14.29 \%$. Similar report 
Table 3. Total Titratable acid of pineapple, watermelon-orange juice blends during storage

\begin{tabular}{cccccccc}
\hline \multirow{2}{*}{ Sample Code } & \multicolumn{7}{c}{ Storage Period (Weeks) } \\
\cline { 2 - 7 } & 0 & 1 & 2 & 3 & 4 & 5 & \% Increase \\
\hline PWO & $0.21 \pm 0.01^{\mathrm{c}}$ & $0.31 \pm 0.01^{\mathrm{a}}$ & $0.35 \pm 0.04^{\mathrm{a}}$ & $0.39 \pm 0.03^{\mathrm{a}}$ & $0.42 \pm 0.03^{\mathrm{a}}$ & $0.45 \pm 0.05^{\mathrm{a}}$ & 53 \\
PWOA & $0.25 \pm 0.01^{\mathrm{b}}$ & $0.27 \pm 0.02^{\mathrm{b}}$ & $0.27 \pm 0.03^{\mathrm{b}}$ & $0.31 \pm 0.01^{\mathrm{b}}$ & $0.34 \pm 0.05^{\mathrm{c}}$ & $0.35 \pm 0.05^{\mathrm{b}}$ & 40 \\
PWOC & $0.27 \pm 0.02^{\mathrm{a}}$ & $0.28 \pm 0.00^{\mathrm{b}}$ & $0.29 \pm 0.02^{\mathrm{b}}$ & $0.30 \pm 0.02^{\mathrm{b}}$ & $0.33 \pm 0.04^{\mathrm{c}}$ & $0.37 \pm 0.04^{\mathrm{b}}$ & 37.03 \\
PWOL1 & $0.28 \pm 0.03^{\mathrm{a}}$ & $0.31 \pm 0.00^{\mathrm{a}}$ & $0.29 \pm 0.01^{\mathrm{b}}$ & $0.29 \pm 0.03^{\mathrm{b}}$ & $0.32 \pm 0.00^{\mathrm{b}}$ & $0.32 \pm 0.01^{\mathrm{c}}$ & 14.29 \\
PWOL2 & $0.29 \pm 0.02^{\mathrm{a}}$ & $0.30 \pm 0.01^{\mathrm{a}}$ & $0.30 \pm 0.01^{\mathrm{b}}$ & $0.32 \pm 0.01^{\mathrm{b}}$ & $0.31 \pm 0.01^{\mathrm{b}}$ & $0.32 \pm 0.02^{\mathrm{c}}$ & 10.34 \\
PWOL4 & $0.29 \pm 0.01^{\mathrm{a}}$ & $0.31 \pm 0.00^{\mathrm{a}}$ & $0.30 \pm 0.00^{\mathrm{b}}$ & $0.30 \pm 0.00^{\mathrm{b}}$ & $0.29 \pm 0.00^{\mathrm{b}}$ & $0.29 \pm 0.01^{\mathrm{c}}$ & 0 \\
\hline
\end{tabular}

$\mathrm{n}=3$. PWO (without preservative); PWOA (Ascorbic acid preserved); PWOC (Citric acid preserved); PWOL1 (1\% Lime preserved); PWOL2 (2\% Lime preserved); PWOL4 (4\% Lime preserved)

Table 4. pH of pineapple, watermelon-orange juice blends during storage

\begin{tabular}{cccccccc}
\hline \multirow{2}{*}{ Sample Code } & \multicolumn{7}{c}{ Storage Period (Weeks) } \\
\cline { 2 - 8 } & 0 & 1 & 2 & 3 & 4 & 5 & \multirow{2}{*}{ Decrease } \\
\hline PWO & $4.50 \pm 0.02^{\mathrm{a}}$ & $4.31 \pm 0.22^{\mathrm{b}}$ & $3.48 \pm 0.02^{\mathrm{e}}$ & $3.14 \pm 0.05^{\mathrm{e}}$ & $3.00 \pm 0.14^{\mathrm{e}}$ & $2.80 \pm 0.04^{\mathrm{e}}$ & 60.71 \\
PWOA & $4.47 \pm 0.32^{\mathrm{a}}$ & $4.42 \pm 0.01^{\mathrm{a}}$ & $4.22 \pm 0.11^{\mathrm{a}}$ & $3.53 \pm 0.01^{\mathrm{c}}$ & $3.44 \pm 0.02^{\mathrm{d}}$ & $3.01 \pm 0.01^{\mathrm{d}}$ & 48.50 \\
PWOC & $4.42 \pm 0.08^{\mathrm{b} .}$ & $4.23 \pm 0.02^{\mathrm{c}}$ & $3.94 \pm 0.08^{\mathrm{b}}$ & $3.21 \pm 0.03^{\mathrm{d}}$ & $3.11 \pm 0.21^{\mathrm{e}}$ & $2.98 \pm 0.05^{\mathrm{d}}$ & 48.32 \\
PWOL1 & $4.21 \pm 0.05^{\mathrm{c}}$ & $4.19 \pm 0.03^{\mathrm{c}}$ & $4.11 \pm 0.25^{\mathrm{b}}$ & $4.08 \pm 0.01^{\mathrm{b}}$ & $3.52 \pm 0.02^{\mathrm{c}}$ & $3.41 \pm 0.03^{\mathrm{c}}$ & 23.46 \\
PWOL2 & $4.18 \pm 0.09^{\mathrm{c}}$ & $4.18 \pm 0.02^{\mathrm{c}}$ & $4.16 \pm 0.01^{\mathrm{b}}$ & $4.13 \pm 0.02^{\mathrm{a}}$ & $4.14 \pm 0.02^{\mathrm{a}}$ & $3.94 \pm 0.06^{\mathrm{a}}$ & 6.09 \\
PWOL4 & $4.03 \pm 0.05^{\mathrm{d}}$ & $4.03 \pm 0.03^{\mathrm{d}}$ & $4.02 \pm 0.01^{\mathrm{c}}$ & $4.01 \pm 0.09^{\mathrm{b}}$ & $4.00 \pm 0.02^{\mathrm{b}}$ & $4.00 \pm 0.03^{\mathrm{a}}$ & 0.75 \\
\hline
\end{tabular}

PWO (without preservative); PWOA (Ascorbic acid preserved); PWOC (Citric acid preserved); PWOL1 (1\% Lime preserved); PWOL2 (2\% Lime preserved); PWOL4 (4\% Lime preserved).

According to Duncan multiple range test different superscripts on means connotes significantly difference $(\mathrm{p}<0.05)$ along the column.

Table 5. Specific gravity of pineapple, watermelon-orange juice blends during storage

\begin{tabular}{cccccccc}
\hline \multirow{2}{*}{ Sample Code } & \multicolumn{7}{c}{ Storage Period (Weeks) } \\
\cline { 2 - 7 } & 0 & 1 & 2 & 3 & 4 & 5 & \% Increase \\
\hline PWO & $1.01 \pm 0.03^{\mathrm{a}}$ & $1.01 \pm 0.04^{\mathrm{a}}$ & $1.04 \pm 0.01^{\mathrm{a}}$ & $1.06 \pm 0.01^{\mathrm{a}}$ & $1.06 \pm 0.03^{\mathrm{a}}$ & $1.07 \pm 0.02^{\mathrm{a}}$ & 5.61 \\
PWOA & $1.03 \pm 0.01^{\mathrm{a}}$ & $1.04 \pm 0.01^{\mathrm{a}}$ & $1.04 \pm 0.00^{\mathrm{a}}$ & $1.05 \pm 0.01^{\mathrm{a}}$ & $1.05 \pm 0.00^{\mathrm{ab}}$ & $1.06 \pm 0.01^{\mathrm{a}}$ & 2.83 \\
PWOC & $1.02 \pm 0.02^{\mathrm{a}}$ & $1.02 \pm 0.03^{\mathrm{a}}$ & $1.03 \pm 0.01^{\mathrm{a}}$ & $1.02 \pm 0.01^{\mathrm{ab}}$ & $1.03 \pm 0.01^{\mathrm{ab}}$ & $1.05 \pm 0.01^{\mathrm{a}}$ & 1.90 \\
PWOL1 & $1.03 \pm 0.01^{\mathrm{a}}$ & $1.04 \pm 0.01^{\mathrm{a}}$ & $1.04 \pm 0.01^{\mathrm{a}}$ & $1.03 \pm 0.01^{\mathrm{ab}}$ & $1.04 \pm 0.01^{\mathrm{ab}}$ & $1.04 \pm 0.02^{\mathrm{ab}}$ & 0.96 \\
PWOL2 & $1.04 \pm 0.01^{\mathrm{a}}$ & $1.04 \pm 0.01^{\mathrm{a}}$ & $1.03 \pm 0.02^{\mathrm{a}}$ & $1.04 \pm 0.01^{\mathrm{a}}$ & $1.04 \pm 0.01^{\mathrm{ab}}$ & $1.04 \pm 0.01^{\mathrm{ab}}$ & 0 \\
PWOL4 & $1.05 \pm 0.00^{\mathrm{a}}$ & $1.05 \pm 0.00^{\mathrm{a}}$ & $1.05 \pm 0.00^{\mathrm{a}}$ & $1.05 \pm 0.00^{\mathrm{a}}$ & $1.05 \pm 0.00^{\mathrm{ab}}$ & ${ }^{\prime} 1.05 \pm 0.00^{\mathrm{a}}$ & 0 \\
\hline
\end{tabular}

PWO (without preservative); PWOA (Ascorbic acid preserved); PWOC (Citric acid preserved); PWOL1 (1\% Lime preserved); PWOL2 (2\% Lime preserved); PWOL4 (4\% Lime preserved).

According to Duncan multiple range test different superscripts on means connotes significantly difference $(p<0.05)$ along the column.

Table 6. Total soluble solids ( ${ }^{\circ}$ Brix) of pineapple, watermelon-orange juice blends during storage

\begin{tabular}{cccccccc}
\hline \multirow{2}{*}{ Sample Code } & \multicolumn{7}{c}{ Storage Period (Weeks) } \\
\cline { 2 - 7 } & 0 & 1 & 2 & 3 & 4 & 5 & \multirow{2}{*}{ \% Increase } \\
\hline PWO & $1.42 \pm 0.07^{\mathrm{ab}}$ & $1.49 \pm 0.02^{\mathrm{b}}$ & $1.52 \pm 0.05^{\mathrm{ab}}$ & $1.61 \pm 0.04^{\mathrm{a}}$ & $1.63 \pm 0.07^{\mathrm{a}}$ & $1.67 \pm 0.03^{\mathrm{a}}$ & 21.80 \\
PWOA & $1.49 \pm 0.11^{\mathrm{a}}$ & $1.50 \pm 0.01^{\mathrm{b}}$ & $1.59 \pm 0.09^{\mathrm{a}}$ & $1.59 \pm 0.06^{\mathrm{a}}$ & $1.62 \pm 0.05^{\mathrm{a}}$ & $1.62 \pm 0.02^{\mathrm{a}}$ & 8.72 \\
PWOC & $1.51 \pm 0.06^{\mathrm{a}}$ & $1.57 \pm 0.03^{\mathrm{a}}$ & $1.62 \pm 0.04^{\mathrm{a}}$ & $1.62 \pm 0.06^{\mathrm{a}}$ & $1.67 \pm 0.04^{\mathrm{a}}$ & $1.67 \pm 0.05^{\mathrm{a}}$ & 10.60 \\
PWOL1 & $1.55 \pm 0.03^{\mathrm{a}}$ & $1.56 \pm 0.05^{\mathrm{a}}$ & $1.61 \pm 0.03^{\mathrm{a}}$ & $1.68 \pm 0.01^{\mathrm{a}}$ & $1.68 \pm 0.02^{\mathrm{a}}$ & $1.69 \pm 0.01^{\mathrm{a}}$ & 9.03 \\
PWOL2 & $1.57 \pm 0.01^{\mathrm{a}}$ & $1.59 \pm 0.01^{\mathrm{a}}$ & $1.64 \pm 0.01^{\mathrm{a}}$ & $1.68 \pm 0.01^{\mathrm{a}}$ & $1.69 \pm 0.01^{\mathrm{a}}$ & $1.69 \pm 0.02^{\mathrm{a}}$ & 7.64 \\
PWOL4 & $1.58 \pm 0.00^{\mathrm{a}}$ & $1.59 \pm 0.02^{\mathrm{a}}$ & $1.59 \pm 0.05^{\mathrm{a}}$ & $1.68 \pm 0.01^{\mathrm{a}}$ & $1.69 \pm 0.00^{\mathrm{a}}$ & $1.68 \pm 0.00^{\mathrm{a}}$ & 6.33 \\
\hline
\end{tabular}

PWO (without preservative); PWOA (Ascorbic acid preserved); PWOC (Citric acid preserved); PWOL1 (1\% Lime preserved); PWOL2 (2\% Lime preserved); PWOL4 (4\% Lime preserved).

According to Duncan multiple range test different superscripts on means connotes significantly difference $(p<0.05)$ along the column. 
was reported during storage of orange juice using chemical preservatives (Akinola et al., 2018; Laryea et $a l ., 2018)$ in the acidity was increase in the free acid may be due to conversion of pectin into pectic acid during extended period storage (Olaniran et al., 2015; Okwori et al., 2017). This shows that that lime effectively controlled the rate at which increase occurred during storage by double-fold when compared with ascorbic and citric acid used in the study. There was significant decrease in the $\mathrm{pH}$ of the fresh juice from 4.50 to 4.03 on addition of $4 \%$ lime as presented in Table 4 . Though not as drastic as $4 \%$ lime, similar observation was observed other preserved juice except in those preserved with ascorbic acid which had no significant difference compared to control (unpreserved). Minimal decrease in $\mathrm{pH}$ of $0.75 \%$ was documented during the 5 weeks of study. The $\mathrm{pH}$ of pineapple, watermelon and orange juice ranged from 2.80-4.50 showing that they were acidic. This observation were in agreement with previous studies (Ibrahim, 2016). Negligible/ no change in $\mathrm{pH}$ of juice preserved with lime showed in the relationship presented from Table 5 with $0 \%$ increase in the free acid content. Bates et al. (2001) reported that low $\mathrm{pH}$ is advantageous influence in the excellent keeping quality of fruits. The specific gravity of the juice for were relatively stable during storage except the unpreserved juice showed a slight increase after the first week of storage recording $5.61 \%$ increase after 5 weeks. There was no change in the specific gravity of juice preserved with $2 \%$ and $4 \%$ lime all through the study. There was no significant difference $(p<0.05)$ in the specific gravity of the juice on the addition of preservatives. The specific gravity of all the samples was the agreement with the guidelines recommended for non- alcoholic drinks/ juice and beverages that do not contain added sugar ranging from 1.01-1.055 g/L (FAO, 2011; Aderinola and Adeniran, 2015). The total soluble solid ( ${ }^{\circ}$ Brix) and organic acid of the juice blend are very important as it can influence the chemical and acceptance by the consumer. Generally, there was increase in percentage of total soluble solid of the juice during storage between $6.33-21.8 \%$ (Table 6). The result was in agreement with Farahmand et al. (2016) who reported that an increase in total soluble solids can contribute to the breakdown of carbohydrates to simple sugars, and biosynthesis of organic acids.

\section{Conclusion}

These studies have shown that lime could be used as effective biopreservative in fruit juice. The product will be beneficial to human health as fruits are widely consumed and lime is readily available and cheap. Lime should be encouraged in food as biopreservative not just for domestic use and cosmetics.

\section{Conflict of Interest}

The authors declare no conflict of interest.

\section{Acknowledgments}

This is to appreciate the technologists of the Department of Microbiology, Landmark University for their support during the study.

\section{References}

Aderinola, A.T. and Adeniran, A.E. (2015). Effects of storage on physicochemical properties of OrangeWatermelon juice. Annals of Food Science and Technology, 16(2), 326-332.

Akinola, S.A., Samson, A., Ajatta, A. and Aworh, C.O. (2018). Croatian Journal of Food Science and Technology. Croatian Journal of Food Science and Technology, 10(1), 8-15. https://doi.org/10.17508/ CJFST.2018.10.1.02

Akusu, O.M., Kiin-kabari, D.B. and Ebere, C.O. (2016). Quality Characteristics of Orange/Pineapple Fruit Juice Blends. American Journal of Food Science and Technology, 4(2), 43-47. https://doi.org/10.12691/ ajfst-4-2-3

Almeida, E.T.D.C., Souza, G.T.D., Guedes, J.P.D.S., Barbosa, I.M., Sousa, C.P.D., Cstellano, L.R.C., Magnani, M. and Souza, E.L.D. (2019). Mentha piperita L . essential oil inactivates spoilage yeasts in fruit juices through the perturbation of different physiological functions in yeast cells. Journal of Food Microbiology, 82, 20-29. https:// doi.org/10.1016/j.fm.2019.01.023

Ameh, B.A., Gernah, D.I., Obioha, O. and Ekuli, G.K. (2015). Production, Quality Evaluation and Sensory Acceptability of Mixed Fruit Juice from Pawpaw and Lime. Food and Nutrition Sciences, 6(5), 532-537. https://doi.org/10.4236/fns.2015.65055

Batra, N.G., Ameeta, S. and Neha, A. (2016). Microbiological analysis of packed fruit juices locally available in Jaipur, India. International Journal of Pharma and BioScience, 7(4), 395-401.

Chanson-Rolle, A., Braesco, V., Chupin, J. and Bouillot, L. (2016). Nutritional Composition of Orange Juice: A Comparative Study between French Commercial and Home-Made Juices. Food and Nutrition Sciences, 7(4), 252-261. https://doi.org/10.4236/ fns.2016.74027

Cruz-Valenzuela, M.R., Tapia-Rodríguez, M.R., Vazquez-Armenta, F.J., Silva-Espinoza, B.A. and Ayala-Zavala, J.F. (2016). Lime (Citrus aurantifolia) Oils. In Victor, R.P. (Ed). Essential Oils in Food Preservation, Flavor and Safety, p. 531-537. 
Amsterdam: Elsevier Academic press.

Ezeigbo, O.R., Ekaiko, M.U., Agomo, N.G., Ojukwu, K. and Nnadozie, A.I. (2015). Antimicrobial Effect of Lime Juice Treatment on the Shelf-Life of Zobo Drink, British Microbiology Research Journal, 6(3), 147-153. https://doi.org/10.9734/BMRJ/2015/15534

Hounhouigan, M.H., Linnemann, A.R., Soumanou, M.M. and Van Boekel, M.A.J.S. (2014). Effect of Processing on the Quality of Pineapple Juice. Food Reviews International, 30(2), 112-133. https:// doi.org/10.1080/87559129.2014.883632

Ibrahim, F.Y., El-Shehawy, S.M. and Ibrahim, M.N. (2013). Effect of concentration process and storage period on quality properties of some fruit and vegetable concentrates. Journal of Food and Dairy Science, 4(7), 359 - 372. https://doi.org/10.21608/ jfds.2013.72078

Ibrahim, M. (2016). Effect of Different Storage Condition on $\mathrm{pH}$ and Vitamin $\mathrm{C}$ Content in Some Selected Fruit Juices (Pineapple, Pawpaw and Watermelon). International Journal of Biochemistry Research and Review, 11(2), 1-5. https:// doi.org/10.9734/IJBCRR/2016/23462

Igbinadolor, R., Yahaya, L. and Jayeola, C.A.S. (2017). Addressing the Post-harvest Wastages and Underutilization of Cashew Apple in Nigeria-A Review. The International Journal of Science and Technology, 5(7), 5-8.

Jittanit, W., Suriyapornchaikul, N. and Nithisopha, S. (2013). The Comparison between the Quality of Lime Juices Produced by Different Preservation Techniques. Procedia - Social and Behavioral Sciences, 91, 691-696. https://doi.org/10.1016/ j.sbspro.2013.08.470

Kaddumukasa, P.P., Imathiu, S.M., Mathara, J.M. and Nakavuma, J.L. (2017). Influence of physicochemical parameters on storage stability: Microbiological quality of fresh unpasteurized fruit juices. Food Science and Nutrition, 5(6), 1098-1105. https://doi.org/10.1002/fsn3.500

Khan, M.M., Al-Yahyai, R. and Al-Said, F. (2017). Introduction and Overview of Lime. In The Lime: Botany, Production and Uses, p. 1-11. CABI e-book. https://doi.org/10.1079/9781780647845.0001

Laryea, D., Wireko-manu, F.D. and Oduro, I. (2018). Formulation and characterization of sweetpotatobased complementary food. Cogent Food and Agriculture, 4(1), 1-15. https:// doi.org/10.1080/23311932.2018.1517426

Okwori, E., Onu, R.O. Adamu, M., Chindo, H., Dikko, H., Odunze, 1.1, Baidu, A.L., Natala, C. and Eze, P. (2017). Production and shelf life determination of fruit/vegetable juices using watermelon, cucumber, pineapple and carrot. African Journal of Food Science and Technology, 8(3), 34-039. https:// doi.org/10.14303/ajfst.2017.015

Olaniran, A.F. and Abiose, S.H. (2018). Proximate and antioxidant activities of bio-preserved ogi flour with garlic and ginger. F1000Research, 7, 1936. https:// doi.org/10.12688/f1000research.17059.1

Olaniran, A.F., Okolie, C., Abu, H.E., Afolabi, R.O. and Owolabi, A. (2019). Preservative Effect of Garlicginger, Sodium Benzoate and Ascorbic Acid in Unpasteurized Cashew Apple Juice. Asian Journal of Scientific Research, 12(3), 414-420. https:// doi.org/10.3923/ajsr.2019.414.420

Shanely, R.A., Nieman, D.C., Perkins-veazie, P., Henson, D.A., Meaney, M.P., Knab, A.M. and Cialdell-kam, L. (2016). Comparison of Watermelon and Carbohydrate Beverage on Exercise-Induced Alterations in Systemic Inflammation, Immune Dysfunction, and Plasma. Nutrients, 8(8), 1-14. https://doi.org/10.3390/nu8080518

Usaga, J., Manns, D.C., Moraru, C.I., Worobo, R.W. and Padilla-Zakour, O.I. (2017). Ascorbic acid and selected preservatives influence effectiveness of UV treatment of apple juice. LWT - Food Science and Technology, 75, 9-16. https://doi.org/10.1016/ j.lwt.2016.08.037 